\title{
The Politics of 'Social Accountability' in England and Germany: Democratic Control and Moral Imperatives
}

\author{
Paola Mattei, Mahima Mitra, and Therese Feiler
}

\section{Abstract}

This paper investigates how politicians in England and Germany approach social accountability during the introduction of markets in the national health care systems. It analyses the discourse among members of parliament during the law making process of the 2012 NHS Health Care Act in England and the 2011 Act for Financing of Statutory Health Insurance in Germany. Generally, the new social accountability reform agenda is attractive to policy makers as it foregrounds public engagement and bottom-up participation (Peters, 2001). Social accountability refers to institutional practices that favour participatory and horizontal mechanisms that depart from traditional hierarchical Principal-Agent forms.

KEYWORDS

Social accountability; democratic accountability; markets; health care reforms; bottom-up; ethics 


\section{INTRODUCTION}

How does one approach the study of accountability in the pre-decisional stages of public policy making, when institutional mechanisms are not yet clearly designed, and policy change has not been yet formally adopted, and ideological contestation is extremely relevant? This article focuses on social accountability as a contested concept and as a discourse defined both as content of ideas and communication process in which they are conveyed. The existing literature on accountability, with its predominant focus on the organisational and structural mechanisms, has not yet given enough attention of the normative contestation underpinning the politics of accountability. This paper aims to contribute to the emerging scholarly debate on the centrality of framing in the accountability reform agendas (Rodan and Hughes, 2014; Goetz and Jenkins, 2001).

The paper adopts a comparative case study approach to investigate empirically the politics of accountability reforms. Post-New Public Management reforms emphasise the organisational demands for further collaboration in the public sector that followed from the fragmentation of agencies, decentralisation of management and marketization reforms (Laegreid and Christensen, 2007; Farazmand, 2001). National administrative traditions influence the way in which public accountability is conceptualised and practiced (Pollitt and Bouakert, 2009). Thus, we do not expect a one-fit-all strategy across different national administrations. The comparative analysis of different conceptualisations of accountability in Germany and England suggests that different countries use the same reform idea, or aspire to similar goals, but they use different meanings stemming from different administrative traditions (Page and Wright, 1999). 
Two legislative reforms are analysed in this paper: the 2012 Health and Social Care Act (NHS) in England and the 2011 Act for Sustainable and Socially Balanced Financing of Statutory Health Insurance in Germany. Both reforms intended to restructure the system of accountability relations and reshape the power authority within the health care systems. They represent key reforms in the field of social accountability and bottom-up approaches to health care (Peters, 2001). How to improve accountability in the public sector is not a new reform agenda, but a longstanding government activity implicating institutional design and practice (Behn, 2001). Political scientists and public law scholars have studied accountability arrangements as structurally organised types of relationships in the public sector (Mulgan, 2003). The literature on public administration and accountability has accepted widely the definition of public accountability mainly based on principal-agent relationship, 'a relationship between an actor and a forum in which the actor has an obligation to explain and to justify his or her conduct, the forum can pose questions and pass judgment, and the actor may face consequences' (Bovens 2007, 448). The possibility of the agent to face consequences for misconduct is a constitutive and a fundamental element of accountability in its most restrictive definition, stressed by Mulgan (2003) and Mattei (2009). Most of the scholarly work on accountability to date reflects the post-decisional relevance of the concept and its applications to the study of institutional mechanisms and formal procedures (Mosher, 1968; Behn, 2011).

However, the politics of accountability reform might include also anticipatory considerations that guide actors' behaviour as they formulate policies and predict the effects of their decisions on others' strategies (Waldron, 2014). The agent might correct his behaviour in order to avoid the consequences that he would face if he decided to embark upon a specific course of action, deviating from his principal's preferences. The calculation of the 
anticipatory effects of the agent's behaviour might lead to adopting different policy options than originally proposed. This is a political process by which actors assess different policy options, and the effects of their decision on accountability. As such, it pertains mainly to the early stages of the policy making process when actors are formulating ideas and debating them. At this early stage of political debates ideological contestation is essential and accountability is a contested ideology (Rodan and Hughes, 2014) This ideological underpinning of accountability reforms is notable during the parliamentary discussions, especially if reforms are politically salient and divisive.

\section{CONCEPTUAL FraMeWORK}

Discursive institutionalism (DI) provides an innovative theoretical framework aimed at explaining policy change through an understanding of the role of ideas in public policy, and, more specifically, how discourse influences policies within institutional constraints (Schmidt, 2008). Given the scarce attention to the politics and framing of accountability as a contested idea in the policy of accountability reforms, it is useful to draw upon DI for two main reasons. First, it has an ideational component (the role of ideas) which explores the causal effects of ideas (cognitive and normative) at different levels of the policy making process. The normative dimension allows us to understand the ideological framing of social accountability. DI has also a second interactive component that we study in this paper when we investigate the law making process of tow reform legislation (one for each country). Interactive discourse in DI takes place in two ways, through coordinative and communicative discourses (Schmidt, 2008; 2011). The former is the focus of the empirical research of this paper. It refers to how actors interact when discussing policy ideas, how they elaborate and 
develop them, in an institutional context. We examine how politicians justify their positions in parliaments. It is particularly useful as agency is not passive, as in constructivist approaches to discourses. Political élites deliberately choose to frame accountability ideas in an instrumental, opportunistic way that reflects and serve their own interests. Metaphors are very important in politics.

What follows is an account and analysis of how policy discourses regarding political and social accountability were elaborated by politicians during the law-making process. How were ideas on accountability conveyed by the UK Coalition Government (ConservativeLiberals) to the Opposition (Labour) and viceversa? Discursive Institutionalism is a useful framework to understand how interactive discourse exerts an effect on policy change, in terms of the representation of ideas and the process by which politicians convey ideas of accountability. The coordinative discourse consists of "the individuals and groups at the center of policy construction who are involved in the creation, elaboration, and justification of policy and programmatic ideas" (Schmidt, 2008:310). Schmidt develops a framework to study policy discourses within an institutional context, whereby actors are constrained by existing structures. Parliamentary committees are highly structured formats of public deliberation, and they are not informal public fora.

This theoretical section wishes to clarify the definition of 'new' social accountability, in relation to political accountability (the more traditional form). Social accountability is a new type and very attractive to reforms worldwide because it foregrounds public participation (Schillemans, 2011) and bottom-up institutional approaches (Peters, 2001). 
Let us first present the main tenets of the most traditional forms of accountability-political accountability. Its most important function is democratic control (Behn, 2001; Mosher, 1968; Waldron, 2014). Voters 'make elected representatives answer for their actions', while politicians in turn can hold those accountable upon whom they entrusted certain powers (Mattei 2009: 37). And for democratic control to function effectively 'there must be a line, no matter how convoluted, running from any act of a public administrator to the electorate' (McGarvey 2001: 26). It is crucial that citizens are able to identify and monitor the line and direction of this accountability relationship (Finer 1941). When we drop electorates from the definition of accountability, then the concept stretches to include almost everything (Page, 2010). Traditional political accountability is built on a parliamentary chain in which voters delegate their sovereignty to representatives in elected bodies, who then delegate tasks to cabinet and the civil service (Waldron, 2014). Political accountability is a key feature in the chain of delegation (Multan, 2003; Page, 2010).

Social accountability is a new type of accountability that this paper focuses on, in relation to the more traditional forms and political accountability particularly. Schillemans et al (2008) call the new type "public" or "direct" accountability to citizens. Schillemans has contributed hugely to the advancement of our understanding of social accountability. It presupposes an accountability relationship between the administration and stakeholders at large, that include the community at large, users' organizations and (civil) interest groups, who exert a pressure on public organizations, obliging them to account for the services they deliver. This is done through, e.g., the media, public reporting, public panels or online information. Thus, there is no fixed format for social accountability, unlike political accountability. Giving account to various stakeholders in society usually occurs on a voluntary basis and has also been labelled horizontal accountability (Schillemans 2008). Unlike political, this form of accountability does not place strong sanctions on those held to account, but leaves users with the options of 'exit' or 'voice' (Hirschman, 1970). 
One of the reasons why politicians find social accountability reforms so attractive is because they appear to fit the process of deliberation and widening participation of decision-making processes. The argument is that deliberation is essential and significant, and the involvement of civil society actors helps to address democratic deficits. Whilst Schillemans and Bovens use these types of accountabilities as analytical tools to advance our understanding of accountability reforms and mechanisms, some argue that 'social accountability' presupposes that a major, normatively relevant shift has already taken place in public service delivery, i.e. the shift from citizens to consumers or 'client' (Aberbach and Christensen 2005). Thus, social accountability may be ideologically framed, and we cannot neglect the analysis of the ideological contestation of different meanings that are given to social accountability in different countries. Our expectation, for instance, in the case of the UK is that social accountability goes hands in hands with enabling markets coordinative mechanisms (Mattei, 2012).

Whilst political accountability is rooted in a transfer of authority, through the 'chain of delegation' attached to the parliamentary system, social accountability is a useful scrutiny of the machinery of the state as users raise their voice and participate to the decision making process. In this view, social accountability is a beneficial addition to democratic accountability promising further democratisation (Keane 2008). Argued similarly, social accountability may present a 're-balancing' within an already increased 'complex web of accountabilities', as public managers now have increased justificatory duties to their clientele, not only to their elected officials and political masters (Page 2006).

While the British idea of accountability typically reflects a liberal ideology (Rodan and Hughes, 2014), the German idea - Rechenschaft - is rooted in the German philosophical 
tradition and reflects the moral duty towards citizens, in that sense, a moral accountability with an ethical dimension to it (Weber, 1919; Jonas, 1979; Schubert, 1998; Ranson, 2010; Buddeberg, 2011). Thus, the German idea of accountability ${ }^{1}$ is entrenched in moral philosophy and is a moral and ethical value. Struggles over accountability reforms in the German case are more influenced by moral considerations and moral conservatism than in the British liberal accountability tradition. . This is our expectation that we will investigate trough the empirical study. The German word Verantwortung — translated, as "responsibility" in English - is central to ethical questions. The author that has influenced the modern meaning of responsibility in Germany is Hans Jonas in his book The Imperative of Responsibility (1973). He highlighted the ethics of responsibility and the need to create collective responsibilities. Verantwortung is not just answerability to a court, but acting responsibly towards other fellows. It is imbued with morality.

Rather than posing social accountability in contrast with other types, this study accepts that accountability relationships imply different formally organized structures that overlap and come into tension sometimes (Mattei, et al, 2013). This is clearly illustrated by the case of health care reforms. In such policy domain, a variety of actors (politicians, bureaucrats, managers, and health professionals) are held to account on the basis of different criteria such as political, economic or financial ones, standards of health care quality or the quality of other service provision (Mattei, et al 2013). They must give an account to patients, taxpayers, politicians, or external regulatory institutions. So from the outset a plurality of different accountability expectations exists, which may at times overlap or even compete.

\footnotetext{
${ }^{1}$ In Germany, we use the term "Rechenschaft" or "Rechenschaftspflicht" which goes beyond the term "Verantwortung". "Verantwortung" can be best translated with the term "responsibility". Verantwortung means to be responsible for a person or an action. In contrast "Rechschaftspflicht" means that you are liable to account towards public or collective interests.
} 
To sum up, this paper defines social accountability for its participatory dimension and direct accountability to citizens. It presupposes the existence of several 'stakeholders' in society who engage with decision makers through different fora than elections, and traditional electoral accountability mechanisms. Social accountability creates a pressure on public organisations, as those organisations are obliged to account for their activities vis-à-vis citizens at large, stakeholders, or (civil) interest groups and users' associations. They do so via the media, public reporting, public panels, or online information and social media.

Schillemans is his seminal work (2008) identifies three central characteristics of direct citizen accountability. First, it depends on the supply-driven provision of information: public service organisations have to deliver sufficient and transparent information on their work. Citizens can make use of various Freedom of Information clauses, but they depend on the information supplied without the powers to demand it (Meijer and Schillemans 2009, 260-261). Second, unlike political and legal forms of accountability, social accountability has no fixed format or process. It mainly takes the form of debates, usually in the media, 'typically started by apparent policy failures or scandals'. Third, instead of possibly strong penalties, like those entailed by political and legal accountabilities, 'citizens have little or no formal capacity to sanction poor performance' They only have the options of 'exit' or 'voice'. Either they exit the organisation — such as by choosing to go to another hospital—or they publicly complain (Schillemans 2008).

In contrast, political accountability refers to those processes in which the accountors are elected politicians who spend public money, exercise public authority, or oversee a public body under public law. Political accountability, in this paper, refers more narrowly to the relationship between the legislature and the executive (Behn, 2001), that is, between elected 
politicians, and bureaucrats, or other appointed civil servants who 'exercise authority on behalf of [these] elected representatives' (Sinclair 1995: 25).

\section{NATIONAL CASE STUDIES}

The National Health Service (NHS) in England is a publicly funded health care system that guarantees free and universal access at the point of delivery. It is a fairly centralised health care system and mainly funded by general taxation. The government owns public hospitals and clinics. Recent reforms have attempted to create external markets in the NHS, but have received strong political opposition. A preliminary document to the 2012 Health and Social Care Act was the Coalition government's 2010 White Paper entitled Equity and Excellence: Liberating the NHS. The White Paper identified the policy ideas to inform reforms for the NHS. The main idea of the whole legislative proposal was to "make the NHS more accountable to patients" (DoH, 2010, p.1). With a careful eye on the 'provider side', the White Paper set out to create the "largest and most vibrant social enterprise sector in the world" (p.36) with independent foundation trusts. The idea was to create an external market and introduce pro-competitive ideas (Ranade, 1998) In the Government's policy discourse, greater autonomy amongst both NHS commissioners and providers was to be "matched by increased accountability to patients and democratic legitimacy, with a transparent regime of economic regulation and quality inspection" (p.27).

The largely self-administered Statutory Health Insurance (SHI) system in Germany is a hybrid form between a market-driven and a central state-controlled system of health care provision, grounded in the principle of solidarity between members, who are often part of the same occupation. The German health care system is based on the insurance system, financed 
jointly by employer and employee contributions, not on universality, and for this reason it is very different from the British NHS. The German system represents the Bismarckian model. Part of the solidarity principle is the parity between employees and employers, who each pay an equal share of an employee's SHI contribution. Individual SHI (the insurers) are funded by the central Health Fund, which collects the employees' and employers' contributions, but has also been supported by a large sum of federal tax funds. Recent reforms have been mainly driven by strategies of recalibration and cost-containment. Unlike the English NHS, the German health care system has no been subject to institutional radical changes, or paradigm shifts. The 2011 Act for Sustainable and Socially Balanced Financing of Statutory Health Insurance was concerned with a re-adjustment of the financing system between private and public actors, as it is discussed later on.

\section{The 2012 Health and Social Care Act (NHS) in England}

Within the framework of the context set by the White Paper, we examine how social and political accountability were conveyed as reform ideas in the parliamentary debates. The 2012 Health and Social Care Act was introduced in the House of Commons on January 19, 2011, and had its second reading on January 31 the same year. It was debated and amendments were discussed in the Public Bill Committee over 28 sittings. Our data is composed of the minutes of these meetings. The Public Bill Committee comprised 26 MPs, the number being proportionate to their representation in the House of Commons: 13 Government members (2 Lib-Dem and 11 Conservative) and 11 Opposition members (10 Labour and 1 Liberal Democratic Union). The Committee debated many substantive issues over 28 meetings between 8 February and 31 March 2011, including new accountability arrangements. 
We explore in this section the ways in which the concept of 'political accountability' and 'social accountability' were used by politicians in relation respectively to two key substantive issues for debate: (i) the role of the Secretary of State for Health, and, (ii) the role of the Health and Wellbeing Boards.

Under the NHS Act 2006, the Secretary of State for Health was de jure directly responsible for providing health services. In practice, however, many of these functions were already delegated to the Strategic Health Authorities (STA) and Primary Care Trusts (PCT). Part 1 of the 2012 Health and Social Care Act made two policy changes. First, directly responsible for the provision of health services became the National NHS Commissioning Board and local commissioning groups. Second, clause 1 of the Bill proposed to revise the duty of the Secretary of State for Health for service provision. The new role reflected a shift from provision to regulation of public services.

The debates on Clause 1 of the Bill focused on the meaning of political accountability, intended as the classic principal-agent relationship between electorate and taxpayers and the Secretary of State for Health. The Opposition's amendments reflected the idea that the Secretary of State for Health be accountable to Parliament for his public health functions and demanded a direct role vis-à-vis the provider side for the Secretary (9. PBC, 1 Mar 2011). They highlighted that their amendments were based on "concerns that the Secretary of State for Health will reduce accountability on his role in the delivery of health services". The Opposition framed their arguments against the changing role of the Secretary of state as a risk to democratic legitimacy. And they were particularly concerned that, under the new 
commissioning structure, duties would be no longer delegated and the Secretary of State for Health would no longer have direct responsibility for commissioning (5. PBC, 15 Feb 2011). In short, the Opposition was concerned about the creation of the market, but presented their concerns using the metaphor of democratic deficit, along the ideological foundations of democratic accountability and popular sovereignty.

The Coalition aimed to deflect this criticism, especially Andrew Lansley, then Secretary of State for Health, a zealous proponent of privatisation (Lansley 2005). In his speech to the Public Bill Committee he repeated that the Bill would not remove the duty to 'promote' a comprehensive health service from the Secretary of State for Health (4. PBC, 10 Feb 2011). Similarly, Mr Burns, Minister of State for Health, claimed "the Bill absolutely preserves the founding principles of a comprehensive health service". He pointed out that Members of Parliament could still raise their constituents' concerns in Parliament by presenting written 'questions'; members of the public and patients could now "hold the health service to account locally" through the Health and Wellbeing Boards and the local Health Watch (ibid.). The Opposition argument and concerns against the change in the role of the Secretary of state were addressed by offsetting unwelcome market pressures against the new social accountability arrangements embedded in the new Health and Wellbeing Boards.

The Health and Wellbeing Boards (HWB) were newly established institutions within local authorities with the aims of promoting integration between the health and social care sectors, and increasing strategic planning. Each HWB was to include at least one democratically elected local councillor. Both the Government and Opposition members of Public Bill Committee were in favour of the establishment of HWBs and considered them to be 
instruments of democratic accountability. The Opposition concerns regarding the local HWBs focused on the number of the democratically elected councillors in these bodies and on the functions and powers of the boards (16. PBC 2011). In short, there was an overall consensus on increasing social accountability and users' participation. The Opposition raised very strong reservations about these new forms of local accountability instruments. Being, in favour of a more traditional political accountability, the Opposition wondered whether the HWBs would have democratic legitimacy at all (1. PBC, 8 Feb 2011).

Another issue discussed was the accountability relationship between the HWBs and Clinical Commissioning Groups (CCG). The Bill proposed to give major responsibility for commissioning health services to local GP commissioning groups as new statutory bodies and therefore to strengthen the role of medical professionals. Here the Opposition was concerned about the lack of formal powers of the HWBs to ensure that commissioning groups would follow the joint health and wellbeing strategy. In terms of political and social accountability, this political debate illustrates how the Coalition's proposal to establish HWBs was an attempt to redefine traditional political accountability into a hybrid new accountability form comprising local participation and social accountability. The Opposition, on the other hand, although appreciating the increased accountability demands at the local level, emphasised the importance of maintaining centralised, and traditional political accountability.

\section{The 2011 Reform in Germany}

The 2009 elections in Germany resulted in a Conservative-Liberal Coalition (CDU/CSU and FDP parties) government coming to power. The 2011 Reform was first discussed in the 
Bundestag (lower chamber) on Sept. 30. After a public hearing held by the Federal Health Committee as well as several closed meetings of that Committee, the Act had a second and third reading in the Bundestag on Nov 12, 2010. On the same day it was voted on and passed to the Bundestag thanks to the Coalition's absolute majority. Whilst none of the Opposition's amendments had been accepted, it unanimously voted against it.

We discuss the meanings of social and political accountability in the German Bundestag debates on the 2011 reform in relation to one substantive modification: (i) the freezing employers' share in the employees' SHI contribution.

Previously, the solidarity principle within the SHI had taken into account, or rather absorbed, economic fluctuations and individuals as parts of a system of work and wage. The SHI contribution was equally shared between employer and employee. The principle of parity took account of the relationship between labour and health, implying employers and employees in the 'solidarity community' of healthcare with the traditional ministerial chain of accountability ensuring the preservation of the solidarity principle. The first draft of the Act rather loosely linked the solution for a 'structural problem', i.e. the SHI's expenses having risen for years faster than their income, with a generic economic orientation that challenged this parity principle. The modification proposed through the new act was presented as follows: "Increasing shares in contribution cause an increase in labour costs [wage costs] and so jeopardize jobs. Economic fluctuations are causing instability on the income side of the SHI. In order to offset these problems, the employers' share is to be fixed, so that the income-dependence of contributions is reduced" (Gesetzentwurf der Fraktionen der CDU/CSU und FDP, 2010, 1). Whilst employees' contributions could rise, freezing the employers' share at $7.3 \%$ (below $1 / 2$ of the $15.5 \%$ ) for the Coalition held the promise to "break out of the automatism that rising SHI expenditures would automatically lead to rising 
labour costs" (ibid., 3). Next year, in 2016, the employees' contribution will rise $0.2 \%$ on average, the health insurers calculate the rate of contribution by themselves. Another interesting effect of those recent reforms is a shakeout or a market adjustment of health insurers. Nowadays, few big players dominate the systems.

In the parliamentary debates, moving away from the old contribution parity raised controversy about the underpinning notion of solidarity, i.e. whether it is to be upheld within the SHI system or not. Health Minister Philip Rösler defended his position by arguing that healthcare costs were decoupled from labour costs "not as a favour to employers...but to prevent unemployment" (Deutscher Bundestag, 2010c). Whilst it was "creating new opportunities in the health insurance system", it was "altogether creating growth and employment" (ibid.). Ulrike Flach, introducing the Act to the Bundestag on Sept. 30, also picked up on the Opposition's claims that politicians were shifting accountability to specific interest groups rather than the citizens as a whole: "Each one of us ... claims for himself to act responsibly for this country, and that is for the whole of the country, not for single interest groups. Our aim is a just, sustainable and competition-friendly healthcare system" (Deutscher Bundestag, 2010a, p.6457). Defending the new, hybrid form of accountability relationships proposed, Flach said that decoupling healthcare from labour costs "is not an act lacking solidarity, but rather secures jobs and, in case of low economic activity and increasing unemployment, prevents a lack of revenue for the Statutory Health Insurance” (Deutscher Bundestag, 2010b, p. 6456).

Furthermore, the general NPM-orientation of the Government was explained by Wolfgang Zöller (CSU), who focused on the healthcare consumer for whom “...our healthcare system needs more economic and medical transparency". In the future, "health insurances, 
recognised patient pressure groups, and national organisations need to have a duty of information. In so far as this is not the case today, these agents need to be increasingly seen as service providers for the patient" (Bundestag, 12. Nov, 2009, p. 279). Zöller's use of the concept of accountability is close to the public or direct accountability towards citizens as defined by Schillemans (2008) . To quote Rösler: "In the end, the money paid in must be at people's disposal for the services. Every Euro has to end up with the people [to be used for] prevention and provision. The system up to now did not offer that"' (Deutscher Bundestag, 2010a, p.6466).

The Opposition was straightforward in terms of its rejection of an idea of accountability that would undermine the principle of solidarity. Defending the traditional Bismarckian welfare state, they defended 'traditional' political accountability for healthcare (Fritz Kuhn, Deutscher Bundestag, 2010a, p.6463). The introduction of the Act by Martina Bunge (The Left) meant that: "solidarity is being buried for good". Freezing the employer's share at $7.3 \%$ implied "passing on all future rises in [SHI] expenses exclusively to the insured ... This is unsocial" (ibid., p.6461). Andrea Nahles (SPD) attacked Health Minister Rösler for "not representing the interests of the insured"; accusing him of being "the chief lobbyist of the 4\% of high earners" and breaking the chain of ministerial political accountability by releasing "employers from the responsibility for the health of employees" (Deutscher Bundestag, 2010b, p.7849).

\section{COMPARATIVE DISCUSSION}

Analysing the interactive discourses in the parliamentary debates between coalition governments and the Opposition parties was useful for understanding actors' strategies and 
positioning in relation to the introduction of path-breaking, unpopular, and pro-competitive ideas and markets in health care systems. Our analysis of the parliamentary acts identified the arguments and metaphors used by members of parliament, both in Germany and in England, in presenting their policy proposals and persuading the Opposition. The study of the interaction between actors helped us to uncover the meanings given by politicians to political and social accountability. Scholars have primarily refereed to accountability as an element of democratic governance (Waldron, 2014) and also a tool for improving organisational performance (Farazmand, 2002). However, politicians used accountability in instrumental and rhetorical ways that serve their ideological and policy interests. Further research is needed to understand the ideological underpinning of accountability. This article represents a first step, but we do not wish to provide definitive answers.

There are two key findings in relation to the British 2012 Health and Social Care Act. First, the legislative debate reveals a tension between traditional and parliamentary forms of political accountability, on one hand, and new horizontal social accountability to patients and users set up by the newly established Health and Wellbeing Boards on the other. Social accountability was advocated by the government as a mechanism to offset the weakening of the delegation chain running from the Secretary of State to Parliament. Had we analysed the policy making process only through a study of the formal arrangements of accountability, we would not have been able to extrapolate the discursive devises used by politicians to adopt the legislation and push it through a reluctant Opposition. Political accountability was invoked as a way to prevent the creation of an external market in the NHS, and the Opposition's concerns were framed as an issue of democratic control (Behn, 2001). 
The second main finding was that the Opposition did try its best efforts to reassert the role of parliament as a forum of accountability with a clear preference for parliamentary representation and the electoral chain as a mechanism of accountability. Due to the Westminster institutional parliamentary rules, the opposition had most of its amendments rejected. However, the discourse was powerful and cannot be neglected in the analysis of accountability reforms. The DI framework used in this paper allows us to understand how accountability was used as a discursive strategy by the Opposition to push back the Government against its original proposal to privatise the NHS. The fundamental concept of 'accountability', as Waldron defines it in his influential work, was instrumentally adapted to the positional strategies of actors and reinterpreted as a 'remedial' democratic instrument against the introduction of markets.

Whilst in the British case, the framing of social accountability is embedded in democratic theory of accountabilities and a solution to an apparent democratic deficit, the German debate does not show an ideological question of democratic deficits. In the German case, moral considerations and the idea of responsibility as ethical commitment to solidarity was the most often used metaphor and discursive device. The idea of accountability as responsibility and solidarity within the Statutory Health Insurance system was questioned through freezing the employer's share. This was a radical change in the accountability idea underpinning the SHI normative framework. The moral and normative underpinning of 'accountability' as moral solidarity clearly emerged during the analysis of the parliamentary debate, against ideas of economic viability and markets creeping in.

In the 2012 Health and Social Care Act, political accountability is mainly defined as accountability to Parliament and it is discussed within the discursive strategy of changing the 
Secretary of State for health responsibility towards parliament, and thus the electorate. Social accountability is understood as being bottom-up local forms of participation within highly formalised set of administrative arrangements applied to the newly created Health and Wellbeing Boards. The policy discourse of accountability revealed a deliberate strategic use of the concept: the idea of 'accountability', for the Coalition Government, meant a remedial strategic instrument to offset the strong opposition against the introduction of an external market in the NHS and further privatisation.

In this paper's analysis of the German context, accountability is understood mainly as a moral duty of safeguarding solidarity in the health care system, rather than merely an administrative mechanism (Mosher, 1968; Rohr, 1978). 'Veranwortung', as used by German politicians, or responsibility is therefore traditionally conceptualised as the moral duty of the State towards its citizens, operationalized in the healthcare domain through the employment-based solidarity principle. The policy discourse during the parliamentary debates was informed by this interpretation of the idea of accountability and rarely distanced itself from it normative use. German politicians, despite diverging views, subscribed to a shared notion of 'Verantwortung'. The moral and philosophical underpinning of the idea in the German discourse studied in this paper put constraints on the rhetorical and instrumental uses of the idea, available to politicians, which were more evident in the British case.

The discursive institutionalist (DI) analysis of how the idea of accountability was used in the context of the parliamentary debates of the 2012 Health and Social Care Act and the 2011 German Act demonstrated that politicians conveyed an instrumental and opportunist discourse on accountability aimed at either overcoming the Opposition's strong attack against privatisation reforms of the NHS, or to preserve the solidarity and ethical values constitutive 
of the German idea of Verantwortung. While accountability mechanisms as an agenda of institutional innovation is predominant in the British political debate, German accountability reflects foremost a moral and ethical duty of the state and politicians towards their citizens, rooted in the concept of Verantvortung as a moral principle. This normative idea stifles policy change, to a certain extent, and it limits the possibility to experiment new types of 'social' accountability associated with horizontal mechanisms and deliberative types of participation.

\section{CONCLUSION}

Democratic accountability is fundamentally based on the notion of popular sovereignty (Behn, 2001). Traditional forms of accountability are built on a delegation chain by which voters delegate their sovereignty to elected representatives, who then in turn delegate tasks to ministers and the civil service. Political accountability is a key feature in the chain of delegation of power. As this paper shows, recent reforms of the delivery and funding of health care systems in England and Germany have adopted a new agenda of accountability reforms, focused on an institutional bottom-up approach (Peters, 2001). Social accountability presupposes a relationship between health care providers and governments, and stakeholders; they include the community at large, users' organizations, and (civil) interest groups, who exert a pressure on public organizations obliging them to account for the services they deliver and fund.

Whilst political accountability is rooted in a delegation of public authority through the "chain of delegation' attached to the parliamentary system, social accountability is a horizontal type of scrutiny by users and citizens. In this view, social accountability is a beneficial addition to 
democratic accountability promising further democratisation (Keane 2008). Argued similarly, social accountability may present a 're-balancing' within an already increased 'complex web of accountabilities', as public managers now have increased justificatory duties to their clientele (Page 2006). The political debate about the creation of Health and Wellbeing Boards in England was illustrative of this re-balancing strategic discourse and politicians' attempts to soften market pressures and address concerns with newly created democratic deficits.

In England, the ideological contestation of accountability was grounded in the normative dimension linked to democratic and constitutional theories of the state (Waldron, 2014). This was not central in the German debate, however, as the empirical data suggest. Calling for a broader and discursive conception of accountability, this paper suggests recognising accountability as a social phenomenon, beyond narrow mechanisms for enforcing political control. The German case illustrates how further research is needed to explore an ethical and moral theory of accountability (Rhor, 1978; Waldo, 1980). Politicians have moral obligations towards citizens that determine their political strategies and also how they frame accountability reforms (Mosher, 1968). The German case suggests that accountability reforms are underpinning also by moral ideologies that dictate fairness, solidarity and integrity. Further research is needed to advance our understanding of the politics of accountability reforms and how metaphors and framing influence the decision making process, and ultimately the policies adopted. 


\section{REFERENCES}

Aberbach, Joel D. and Tom Christensen. (2005) Citizens and Consumers - A NPM Dilemma. Public Management Review, 7(2) (June): 225-246.

Behn, Robert (2001). Rethinking Democratic Accountability. Washington, DC: The Brookings Institution.

Bovens, Mark. (2007) Analysing and assessing accountability: a conceptual framework. European Law Journal, 13(4): 447-468.

Bovens, Mark, Thomas Schillemans, and Paul T'Hart. (2008) Does Public Accountability Work? An Assessment Tool, Public Administration , 86: 225-242.

Buddeberg, Eva. (2011) Verantwortung im Diskurs: Grundlinien einer rekonstruktivhermeneutischen Konzeption moralischer Verantwortung im Anschluss an Hans Jonas, Karl-Otto Apel und Emmanuel Lévinas. (Berlin; New York: De Gruyter)

Bundestag, 12. Nov, (2009) Plenarprotokoll 17/5, Fortsetzung der Aussprache zur Regierungserklärung der Bundeskanzlerin Angela Merkel.

Department of Health (DoH), 2010. Equity and Excellence: Liberating the NHS (Cm 7881), 12 July 2010.

Department of Health (DoH), 2012. The NHS Constitution. DoH, 2012.

Deutscher Bundestag, 2010a. 62. Sitzung 30. Sept, 2010. Plenarprotokoll 17/62.

Deutscher Bundestag, 2010b. 12. Nov, 2010. Plenarprotokoll 17/72.

Deutscher Bundestag, 2010c. Ausschuss für Gesundheit, Öffentliche Anhörung zum Thema GKV-Finanzierungsgesetz, 25. Oct, 2010. Protokoll No. 17/21. 
Farazmand, Ali (2002a) Administrative ethics and professional competence: accountability and performance under globalisation. International Review of Administrative Sciences. 68: 127-143

Farazmand, Ali (2002b) (Ed.) Modern Organizations: Theory and Practice. Westport, CT: Praeger.

Gesetzentwurf der Fraktionen der CDU/CSU und FDP, Entwurf eines Gesetzes zur nachhaltigen und sozial ausgewogenen Finanzierung der Gesetzlichen Krankenversicherung (GKV-Finanzierungsgesetz - GKV-FinG), 28.Sept 2010, Deutscher Bundestag, Drucksache 17/3040

Goetz, A. and R.Jenkins (2001), Hybrid Forms of Accountability: Citizen engagement in institutions of public sector oversight in India, Public Management Review, 3,3, 363383.

Hirschman, A (1970) Exit, voice and loyalty: responses to decline in firms, organisations and states. Cambridge: Harvard University Press.

Hood, Christopher. (1991) A public management for all seasons? Public administration, 69(1): 3-19.

Hood, Christopher. (2000) The Art of the State. Culture, Rhetoric, and Public Management. New York: Oxford University Press.

Hood, Christopher. (2011a) Blame avoidance and accountability: Positive, Negative or Neutral?, in Dubnick Melvin and George Frederickson (eds.). Accountable Governance: Problems and Promises. New York: M.E. Sharpe, pp.167-179. 
Hood, Christopher. (2011b) A public management for all seasons? Afterword: bringing back agents, in R.A.W. Rhodes (ed.) Public Administration: 25 years of analysis and debate. Oxford: Wiley-Backwell. pp. 199-214.

Jonas, Hans. (1979) Das Prinzip Verantwortung; Versuch einer Ethik für die technologische Zivilisation. Frankfurt a. M.: Insel-Verlag.

Keane, John. (2008) “Monitory Democracy”?, Paper prepared for the ESRC Seminar Series, 'Emergent Publics', The Open University, Milton Keynes, 13th-14th March 2008.

Laegreid, P and T. Christensen (2007), The Whole-of-Government Approach to Public Sector Reform, Public Administration Review, 67, 6, 1059-1066

Lansley, Andrew. (2005) "Extract from: The Future of Health and Public Service Regulation”, Speech delivered 09 July 2005. Available online at: http://www.andrewlansley.co.uk/newsevent.php?newseventid=21

Mattei, Paola. (2009) Restructuring Welfare Organisations in Europe: From Democracy to Good Management? Basingstoke: Palgrave Macmillan.

Mattei, Paola. (2012) Market accountability in schools: policy reforms in England, Germany, France and Italy, Oxford Review of Education, 38, 2: 1-20.

Mattei, P. Mitra, M., Vrangbæk, K., Neby, S. and Byrkjeflot, H. (2013) "Reshaping public accountability: Hospital reforms in Germany, Norway and Denmark", International Review of Administrative Sciences, 79, 2, 249-270

Mattei, P. 2016 (Ed.) Public Accountability and Health Care Governance. Basingstoke: Palgrave Macmillan.

Mosher, Fredrick (1968). Democracy and Public Service. New York: Oxford University Press. 
Mulgan, R. (2003) Holding Power to Account: Accountability in Modern Democracies, Palgrave.

Page, Edward C. and Vincent Wright. Eds.(1999) Bureaucratic Elites in Western European States. Oxford: Oxford University Press.

Page, Edward. (2010) Accountability as a bureaucratic minefield: lessons from a comparative study. West European Politics, 33(5): 101-1029

Page, Stephen. (2006). The web of managerial accountability: the impact of reinventing government”. Administration \& Society, 38(2): 166-197.

Peters, Guy (2001). "Government Reorganization: Theory and Practice," in Ali Farazmand, (Ed.) Modern Organizations: Theory and Practice. Pp. 159-180. Westport, CT: Praeger.

Ranade, W. (1998) Markets and health care. London: Routledge.

Ranson, Ina (2010) Verantwortung in Germany. Encountering the Sense of Responsibility. In Edith Sizoo (ed.) Responsibility and Cultures of the World, Brussels: Peter Lang, pp.192-211

Rodan, R. and C. Hughes (2014) The Politics of Accountability in Southeast Asia. The Dominance of Moral Ideologies. Oxford: Oxford University Press.

Rohr, John (1978). Ethics for Bureaucrat. New York: Marcel Dekker.

Romzek, Barbara and Dubnick, Melvin. (1987). Accountability in the public sector: lessons from the challenger tragedy. Public Administration Review, 47(3): 227-38.

Schillemans, Thomas. (2008) Accountability in the Shadow of Hierarchy: The Horizontal Accountability of Agencies. Public Organization Review, 8(2): 175-194. 
Schillemans, Thomas (2011) Does Horizontal Accountability Work? Evaluating Potential Remedies for the Accountability Deficit of Agencies, Administration and Society. $43: 387-416$

Schmidt, V (2008), Discursive Institutionalism: the Explanatory Power of Ideas and Discourse, Annual Review of Political Science, 11: 303-326.

Schubert, Jörg. 1998. Das "Prinzip Verantwortung" als verfassungsstaatliches Rechtsprinzip: rechtsphilosophische und verfassungsrechtliche Betrachtungen zur Verantwortungsethik von Hans Jonas. 1st ed., Baden-Baden: NomosVerlagsgesellschaft.

Waldron, Jeremy (2014) Accountability: Fundamental to Democracy, New York University School of Law, Research Paper, no.14-13.

Waldo, Dwight (1980/1992). The Enterprise of Public Administration. Novato, CA: Chandler \& Sharp.

Weber, Max. (1919) Politik als Beruf. Munich; Leipzig: Duncker \& Humblot. 